\title{
The United States and the Payment of an Indemnity by Germany
}

\author{
By Frank Plachy, Jr. \\ Editor, The Americas, The National City Bank of New York
}

$I^{\mathrm{T}}$ $\mathrm{T}$ is curious how little attention is being paid in the United States to the possible effects on this country of the payment by Germany of a reparation indemnity to France, Great Britain and the other countries which expect to share in the gold, goods or services which Germany may be compelled to give up. This lack of interest is not confined to the United States, but typifies the press of England and the other European countries, in all of which there is apparently a general agreement on the part of the press and public that the United States, having allegedly profited more from the war than any other country, should pay more of the costs of repairing the damage than any other.

In the sessions of the various meetings of the premiers at Paris, Spa, Boulogne and London, the economic interests of the United States in the means adopted for securing the indemnity have been absolutely ignored. But it is clear to everybody that the peace settlement is not a matter of boundaries or nationalities but of economic agreements, and that the manner in which those agreements are made and carried out is a matter of profound and far-reaching importance to every industry and every individual in the United States. There appears to have been a general unanimity of opinion among those who have taken part in these conferences that the main interest of the United States is to obtain repayment of its loans to the Allied countries and that any means that will rehabilitate the industries of
France, England and the others in order that the debt may be paid ought to be accepted by this country.

But the world is an economic unit and we are the largest integral part of that unit. It is all very well for a group of European statesmen to formulate their plans, but economic laws will assert themselves in spite of any manmade attempts to circumvent them. No economic law has been more often demonstrated than that great losses of wealth fall on those who possess the most. When a great calamity such as the world war takes place, followed by a period of inaction and disorganization, there is a tremendous destruction of capital and of consumable gcods. This loss can not fall on those who have nothing; it falls where wealth exists in the form most easily reached. In the present world situation there is more available wealth in the United States than in any other country and it may be safely assumed that, during the next fifty years, this country will pay most of the cost of the recent conflict, just as it paid most of the French indemnity to Germany in 1871. This payment will be exacted from us in many ways, but its most clearly discernible effects will probably come through a reduced standard of living in this country, accompanied by gradually falling commodity prices for a considerable period. In 1871 commodity prices, considered in connection with the purchasing power of the monetary mediums then in use, started on their long decline in this country because of the opening up of great areas 
to agricultural production and the quick and easy delivery at the seaboard of the product of these American farms. The fall in prices, which is probably now well started, will be due to the two-fold causes of decreased purchasing power through world poverty and the super-production of manufactured goods that will result if the present policy of the Allied nations in collecting the indemnity from Germany is carried out.

Professor Simon N. Patten and other economists have shown clearly in their writings that neither industrial losses nor gains can be localized. Debts and losses are actually paid in the end by those whose industry is hardest hit as the result of capital sunk and lost unproductively. The European war caused the greatest loss of capital the world has ever seen, and the important point is that while the loss has been sustained it has not yet been paid for. In other words, the process of liquidating this debt, which as an economic problem is not concerned with national boundary lines, has not yet started nor have plans yet been made that will accelerate the process.

\section{The Economics of Indemnities}

Concerning the payment by Germany a few things may be noted: The indemnity must be paid in gold, goods or services. Germany has no gold, practically speaking. If the payment is made in goods, a market for the goods must first be found. If the payment is made in services, for instance, by the employment of large numbers of German workmen in the urgent task of rebuilding the devastated zone in northern France, nearly all the difficulties encountered in securing payment by means of the first two methods are immediately removed, and advantages of an obvious character take their place.
The last-named manner of paying for Germany's destruction of France's great industrial district appeals to the best American public opinion as the manner in which the greatest advantage would accrue to France, which is to get 52 per cent of the total indemnity payment, while at the same time it would exert less effect than any other method in retarding the economic stabilization of the world and it would be less likely to exert a harmful effect on the industries of the United States than any other method.

It is obvious that if Germany is to pay the indemnity through the superproduction of manufactured goods, great export markets must be built up. In the present case, both England and France are determined that their markets are not to be flooded with German goods, although, indemnity aside, unemployment already exists in certain British industries because of their inability to compete with the much lower production costs of German manufacturers. Where is Germany to secure a market that will absorb such tremendous quantities of goods as will allow the creation of favorable balances and the eventual transfer of these balances to France, England and the other participants in the payments? Clearly, public opinion in both France and England regards the United States as the great clearing house through which German goods may be sold and credits created.

This brings the matter to the point where it first actually touches the American people in a manner obvious to all. German goods are already coming to the United States in a steadily increasing stream and their presence here is being felt in the markets, just as they are being felt in the markets of England, Belgium, Holland and other countries. The first reaction here to these goods is a 
demand for a protective tariff against German products. Whether scientific or not, and whether based on sound economic principles or on unsound propositions, it may safely be assumed that a strong effort will be made to protect the markets of the United States against competition from German goods, manufactured under lower production costs, lower living costs and the lower prices for raw materials available to German manufacturers as a result of the exchange situation.

The following table supplied by the United States Department of Commerce shows the significant trend already apparent in Germany's foreign trade and which the tariff wall will be expected, with doubtful results, to change. It shows Germany's trade with the leading countries for the third quarter of 1920 as compared with the quarterly average for 1913. All figures are in pounds sterling calculated at $\$ 4.86$. It will be seen that Germany's exports to the United States were three times as great as to England in the third quarter of 1920 . It will also be noted that while England's exports to Germany reached 40 per cent of the pre-war amount, the exports of the United States reached 70 per cent of the pre-war figure. The difficulty lies in the fact that Germany sent us manufactured goods in which labor was the chief element of value, while our exports to Germany were chiefly food and raw material, notably cotton.

\section{TARIFfs Will Not Remedy}

The chief difficulty for the United States is going to be that, on a large percentage of the German goods against which a tariff will be levied, the only effect will be to increase the selling price of the goods to the American consumer. This may protect that part of our manufacturing capacity devoting itself only to home needs, but where does it leave the manufacturer who makes goods for export and who must sell them in South America, Africa or

German Imports

\section{Countries}

United Kingdom.

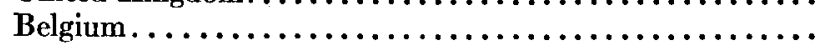

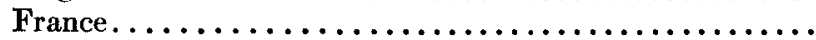

Italy.

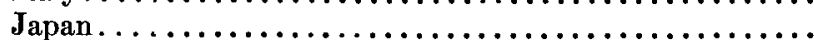

United States. . . . . . . . . . . . . . . . . . . . . .

India.

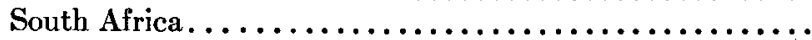

Canada.

German Exports

United Kingdom. . . . . . . . . . . . . . . . . . .

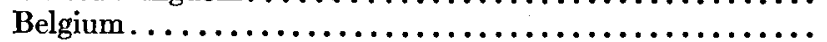

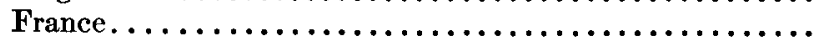

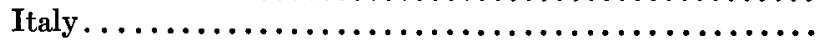

Japan . . . . . . . . . . . . . . . . . . . . . .

United States . . . . . . . . . . . . . . . . . . . .

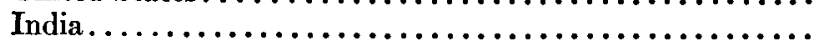

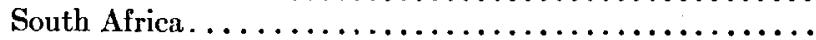

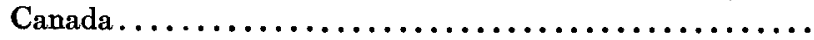

July to

September

1920

$\$ 8,751,000$

$9,380,000$

$33,057,000$

$6,469,000$

845,000

$6,798,000$

$12,120,000$

381,000

82,000

$\begin{array}{rr}\$ 10,169,000 & \$ 4,591,000 \\ 9,404,000 & 13,297,000 \\ 8,668,000 & 7,612,000 \\ 3,434,000 & 2,750,000 \\ 335,000 & 45,000 \\ 18,330,000 & 14,011,000 \\ 4,542,000 & 1,200,000 \\ 503,000 & 32,000 \\ 184,000 & 173,000\end{array}$


the Far East in open competition with German and other European manufacturing nations? The tariff against German goods may protect part of this country's manufacturers, but it inevitably will tend to keep up the cost of living and will make it impossible for the export manufacturer to turn out his goods cheaply enough to assure their being sold in the foreign field. Thus, if the situation has been correctly stated here, little permanent hope ought to be placed in a high protective tariff either for protecting American markets or assisting the world back to an industrial and economic equilibrium.

Great discord exists in Europe concerning the 12 per cent so-called tax on exports of German goods to be levied as an additional indemnity. This tax has attracted little attention in the United States, but in many newspaper and magazine articles it appears to be assumed that the tax is actually to be levied directly against the exports; that is, that German exporters would have to add that amount to the selling price of their goods, thus removing to that extent the differential now existing in favor of the German manufacturer by reason of his lower production costs. The facts in the matter are quite different. The Allied nations in assessing this additional indemnity simply used the total volume of German exports as a barometer by which the amount of the tax is to be calculated. The German Government is to pay it and it is given entire latitude as to means of recouping itself. It may levy a tax on liquor, tobacco or anything else in order to raise the money for this payment; or it may assess an actual export tax graduated in such a way that the products of which Germany has nearly a monopoly must pay most of it while products which are actually competitive with other nations would be lightly affected. In other words, the so-called export tax is not an export tax at all and bears no relation to export in case theGerman government should decide to raise the money in some other way. Thus, it would appear that those in this country who have assumed that the 12 per cent German export tax would be the practical equivalent of a 12 per cent import tax levied by this country against German goods have been ill-informed.

In a way, the position of the United States at this time is not unlike that of England at the close of the FrancoPrussian war. France paid the indemnity to Germany by means of bond issues which it exchanged with its own people for the bonds representing their foreign investments. These foreign investments were then sold, principally in London, and the credits thus created were transferred in the form of goods, gold or commercial bills to Germany. One of the first effects after this large sum of liquid capital and great supplies of raw materials were introduced into Germany was to spur the export trade of that country, the result being that England, with no direct part in the war, was flooded with cheaply produced German goods, with resulting unemployment and industrial slackening.

\section{EFfects on the United States}

At the present time, the United States is threatened with the same experience that England had after the Franco-Prussian war, with the added complication that we have done a large part of the financing of destruction and now appear likely to assume the financing of reconstruction whether we wish it or not. We contributed, in an economic sense, to an orgy of wealth destruction so great that no nation or group of nations can ever hope to actually pay for the large damage 
done, but insofar as the damage is repaired, it will be paid for by those whose wealth is the greatest. This payment will be exacted by means of the general lowering of values which will take place through falling prices and through the inability of the world to resume, at least for a long time, its normal buying and consuming habits.

If the beliefs herein expressed are sound, it is clear that the United States will be damaged by the turning out on the part of Germany of a great volume of cheaply-produced manufactured goods with which to create credits for transfer to France, England and others. It is clear that we require greater markets for our permanent prosperity than those within our own borders, but if we keep up our domestic manufacturing costs and the selling prices of our goods, we automatically shut ourselves out of the competitive export field. A protective tariff protects only some of us, while the tax to be assessed as an additional German indemnity can not be said to be a protection at all.

What, then, remains as a remedy by means of which Germany may be made to pay, but which will also protect American industry from unjust discrimination in order that France may collect and which will also not retard the restoration of normal conditions throughout the world? Assuming, as nearly all do, that Germany has the ability to pay, but that the problem lies in securing satisfactory means of transferring the payment, the whole matter resolves itself into a question of foreign exchange, if payment is to be made in goods, or a monetary question, if payment is to be made in services. The first will involve the world and will retard recovery everywhere, the second will be a purely 'domestic matter for Germany in which outsiders will have no concern.

It is a profound error to say that such a huge debt as the German indemnity can be paid only in goods. Debts can often be more easily and satisfactorily paid in services than in goods and the present instance presents such a case. If Germany, instead of being compelled to build up for herself the world's most efficient industrial machine in order that goods may be manufactured and sold for the purpose of making indemnity payments, is allowed to use the labor and materials of her own people in rebuilding northern France, every objection that might be raised in the United States to the manner of paying the indemnity would be removed.

The difficulty with the present plan of compelling Germany to sell goods throughout the world is that in the end it helps Germany more than anyone else. After the debt has been paid, or after Germany finds herself strong enough to refuse further tribute, the statesmen of France and England may find themselves confronting a creature of their own making which will be intent on their destruction. Divesting the indemnity of all elements except those that are basic, and looking at the actual possibilities of the case from every angle, it is apparent that Germany can pay only in work. This work may be performed in German factories and then done over again in the seeking of markets and the means for the transference of the resulting credits to France, or it may be done directly in northern France. The demand for large, annual contributions in cash is, in the present case, a political and not an economic demand, and there are signs that outside of political circles the people of France are beginning to see this problem in its true light.

If Germany is compelled to sell goods made in its own factories in order to raise cash for the indemnity 
payments, then it will be inevitably constructing a marvelously efficient industrial machine which will remain to turn out goods after the necessity for making indemnity payments has passed. On the other hand, if Germany is allowed to do what it has already offered to do, that is, pay off a considerable share of the indemnity by means of the labor of its people directly expended on reconstruction or any kind of construction work in northern France, it is France that will possess the industrial machine. Germany will then be able to convert a considerable part of the indemnity problem from an international question to one that is purely domestic. It can pay the workers in its own paper money, which is good in their hands but in no one's else, and it can purchase construction material in the same way.

The folly of not doing this is incredible. Lack of labor no less than lack of funds is delaying the rebuilding of the devastated regions. It is a fact that while workers are idle in Germany, thousands of Italian and Spanish laborers are engaged in the work of rebuilding northern France. These workers remit a large share of their wages to their home countries, thus aggravating the abnormal condition of the French exchanges. German workers, on the other hand, would absolutely remove this obstacle to exchange rectification and would accelerate more than by any other conceivable plan the actual and vitally important work of rebuilding homes, factories, roads, canals and all other manner of construction needed in the occupied zone. The following quotation from the Paris correspondence of the London Economist dated January 18 is in point:

That the demand for certain kinds of labor in this country is still great is seen by the fact that large numbers of Spanish and Italian workers are constantly employed in the devastated departments. Practically the whole of these belong to the unskilled categories, and are engaged in the preliminary work of restoring farming land to cultivation and the construction of roads, etc. The evil that has to be feared in this country as time goes on and it becomes possible for the work of reconstruction to be taken in hand in earnest is a serious scarcity of labor, that will probably prove as great a hindrance to complete economic restoration as the present lack of funds to meet the necessary expenditure and the high prices of all kinds of raw materials.

In this connection it must be remembered that France lost 57 per cent of all its young men between the ages of seventeen and thirty-one during the war, so that the supply of workers on whom industry may draw has been sadly depleted. After a two-months' inquiry, it is now announced (March 21) that the Conferation Generale du Travail, which corresponds to the American Federation of Labor, has decided to favor the importation of German workers for reconstruction work. Labor leaders are said to have announced that if dependence were to be placed wholly on French labor for this work, it would take another forty years to finish the job. If this plan goes into effect, no financial operations will be necessary and Germany will simply be credited with the amount it pays out in its own money for wages and for material. Thus the necessity now confronting France for raising large reconstruction loans would be lessened and the strain on the financial community lightened to that extent.

All in all, it would appear clear that America's interest in this matter is very definite and plain. We are interested in helping the world to get back to normal. We understand full well that whatever settlement is ar- 
rived at with Germany must be inevitably reflected in the United States, since we are now taking far too great a part in the economic organization of the world not to be affected by whatever happens in the dealings between Germany, France, Great Britain and the others concerned. This country has put up probably fifteen billion dollars since the European conflict began, counting governmental credits and private commercial advances, and if unsound principles underly the indemnity agreement it will mean that the depreciation of values in the United States will make it necessary for us to pay this sum twice over.

What ought to be done is to keep the entire matter as much a domestic problem for Germany as possible. Prosperity begets prosperity, just as depression contaminates its neighbors like a rotten apple in a barrel. The world can not be prosperous unless economic peace reigns in Europe, and Europe can not approach such a peace until Germany is normally at work. Without the restoration of Europe it is hopeless to expect any decisive return to the fully employed condition of industry in this country that Americans would like to see. Therefore, whatever decisions are arrived at in the next conference on the indemnity should receive much more active attention in this country than has characterized any of the discussions sofar held.

\title{
The Principal Factors to Be Considered in Connection with the Cancellation of the European Indebtedness to the United States
}

\author{
By C. E. McGurre \\ Washington, D. C.
}

$\mathrm{T}$ THE Ministries of Finance of the world have had to conduct their inventories of national financial resources in recent years under conditions of exceptional difficulty, and the official reports even of some of the larger countries, to say nothing of those whose sovereignty has only lately been recognized, have not been published and made available as early as usual. But the budgetary speeches have had to be made, and these, together with official memoranda such as were filed at the Financial Conference in Brussels (September 23 to October 8, 1920), have furnished some material for quasi-official reports, for the publications of public and private banking institutions and for numerous studies of individual students of public and private credit. While I shall not have occasion, from the very nature of the considerations that $I$ am advancing here, to present any exhaustive series of quotations from this material, I believe I may fairly say that an official source can readily be pointed out for all the figures which $I$ have occasion to give, - a source in no case confidential, but, on the contrary, available to any who could have occasion to consult it.

With a view to approach the subject in an orderly way, let me first indicate the amount and origin of the indebtedness. Then it will be proper to discuss the economic significance of this indebtedness, its relation to the stability of governments and to the orderly conduct of business throughout 